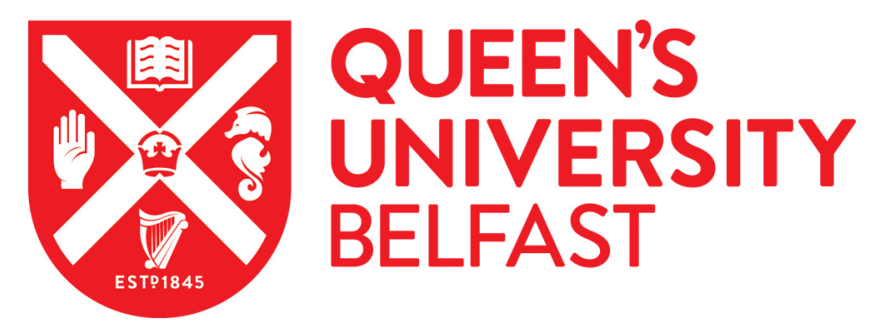

\title{
Predictable Pathways? Negotiating Risk in the Context of Marginalisation and Social Exclusion
}

McAlister, S. (2008). Predictable Pathways? Negotiating Risk in the Context of Marginalisation and Social Exclusion. Current Issues in Criminal Justice, 20 (1), 14-27.

Published in:

Current Issues in Criminal Justice

Queen's University Belfast - Research Portal:

Link to publication record in Queen's University Belfast Research Portal

\section{General rights}

Copyright for the publications made accessible via the Queen's University Belfast Research Portal is retained by the author(s) and / or other copyright owners and it is a condition of accessing these publications that users recognise and abide by the legal requirements associated with these rights.

Take down policy

The Research Portal is Queen's institutional repository that provides access to Queen's research output. Every effort has been made to ensure that content in the Research Portal does not infringe any person's rights, or applicable UK laws. If you discover content in the Research Portal that you believe breaches copyright or violates any law, please contact openaccess@qub.ac.uk. 
THE UNIVERSITY OF SYDNEY

FACULTY OF LAW

\title{
CURRENT ISSUES IN CRIMINAL JUSTICE
}

\author{
Special Issue
}

The Criminalisation and Punishment of Children and Young People

Issue Editor: Professor Phil Scraton, Queen’s University, Belfast

\section{Journal of the Institute of Criminology}




\section{CURRENT ISSUES IN CRIMINAL JUSTICE \\ Volume 20 Number 1 July 2008 \\ Issue Editor: Professor Phil Scraton \\ Executive Editor: Professor Mark Findlay \\ Production Editor: Dawn Koester \\ Book Review Editor: Dr Arlie Loughnan}

Current Issues in Criminal Justice is published three times per year, in July, November and March. This issue of Current Issues in Criminal Justice forms the first of three issues published in the twentieth volume. Volume 20 Number 2 will be published in November 2008. Current Issues in Criminal Justice Number 1 (October 1989) and Number 2 (March 1990) should be regarded as forming Volume 1, Numbers 1 and 2, respectively.

The views expressed in this issue are those of the individual authors and do not necessarily reflect those of the Institute of Criminology or the institution with which they are affiliated. Whilst every reasonable care has been taken in the preparation of this publication, no liability is assumed for any errors or omissions. Current Issues in Criminal Justice is a peer reviewed journal. The Editorial Board would like to thank the reviewers of submissions to this issue of the Journal.

ISSN 1034-5329

(C) 2008 Institute of Criminology University of Sydney. This work is copyright. Apart from any fair dealing for the purposes of private study, research, criticism or review as permitted under the Copyright Act, no part may be reproduced by any process without written permission. Inquiries should be addressed to the Director, Institute of Criminology, University of Sydney, Faculty of Law, 173-175 Phillip Street, Sydney NSW 2000, Australia.

Typeset by the Institute of Criminology.

Printed and bound by Ligare Printery, Sydney, Australia.

\section{Subscriptions}

Subscription rates within Australia (gst incl.): \$110 (1 year), \$209 (2 years), \$308 (3 years) Overseas subscriptions: \$115 (1 year), \$220 (2 years), \$325 (3 years). Single copies of the current issue are \$44. Back issues are available for \$27.50. For subscriptions in North America, contact Gaunt, Inc, who are sole distributors of the journal in that country (Gaunt Building, 3011 Gulf Drive, Holmes Beach, Florida 34217-2199 USA).

\section{Membership}

Membership to the Institute of Criminology includes a Journal subscription, entry to seminars and 10\% discount on Institute publications. Contact the Institute for details.

\section{Contact details}

Institute of Criminology, Sydney University Law School. 173-175 Phillip Street, Sydney, NSW 2000, Australia Ph: 61293510239 Fax: 61293510200

e-mail: d.koester@usyd.edu.au <www.criminology.law.usyd.edu.au>

Current Issues in Criminal Justice is indexed in APAIS: Australian Public Affairs Information Service, produced by the National Library of Australia, and in CINCH, the Australian Criminology Database, produced by the Australian Institute of Criminology. Both databases are available on-line or in CD-ROM format. Contact: INFORMIT, phone: (03) 9341 3265; email: <info@rmitpublishing.com.au>.

Current Issues in Criminal Justice is published online at Informit: <http:// search.informit.com.au>, and at HeinOnline: <http://heinonline.org>. 


\section{Current Issues in Criminal Justice Editorial Board}

Associate Professor Eileen Baldry, University of New South Wales

Dr Harry Blagg, University of Western Australia

Professor David Brown, University of New South Wales

Professor Terry Carney, University of Sydney

Dr Judy Cashmore, University of Sydney

Professor Janet Chan, University of New South Wales

Professor Dorothy Chunn, Simon Fraser University

Professor Chris Cunneen, University of New South Wales

Professor David Dixon, University of New South Wales

Professor Mark Findlay, University of Sydney

Professor Andrew Goldsmith, Flinders University

Dr David Indermaur, University of Western Australia

Associate Professor Gail Mason, University of Sydney

Associate Professor Jude McCulloch, Monash University

Mr David McDonald, Australian National University

Professor Luke McNamara, University of Wollongong

Associate Professor Sharon Pickering, Monash University

Professor Scott Poynting, Manchester Metropolitan University

Professor Rick Sarre, University of South Australia

Dr Kristin Savell, University of Sydney

Professor Martin Schwartz, Ohio University

Professor Phil Scraton, Queen's University Belfast

Professor Elizabeth Stanko, Royal Holloway University of London

Professor Philip Stenning, Keele University

Professor Julie Stubbs, University of Sydney

Associate Professor Julia Tolmie, Auckland University

Professor Stephen Tomsen, University of Western Sydney

Professor Kate Warner, University of Tasmania

Professor Rob White, University of Tasmania

\section{Institute of Criminology}

\section{Co-Directors}

Staff

M Lee, BA (Newc) BA (Hons) PhD (UWS)

Associate Professor G Mason, LLB (Qld) DipCrim (Melb) MA (SUNJ) PhD (La Trobe)

Deputy Directors

Professor M Findlay, BA LLB (ANU) LLM (Syd) DipCrim MSc (Edin)

Professor J Stubbs, BA (Hons) (Woll) MA (Tor)

Professors

T Carney, LLB DipCrim (Melb) PhD (Monash)

D Chappell, BA LLB (Hons) (Tas) PhD (Cantab)

P O’Malley, BA (Hons) (Monash) MA (Dist) (Wellington) PhD (LSE)

Adjunct Associate Professor

PB Shea, BHA GradDip (Health Admin) (UNSW) BA DipEnvStud MEnvPlan (Macq) MB BS BD MPH DipCrim (Syd) DPM (RANZCP) FRANZCP, FRACMA, FAIM, FAFPHM, FACLM, AFCHSE

Senior Lecturers

GB Coss, LLB LLM (Hons) (Syd) GradDip Inf\&LibStud (Curtin)

BA McKillop, LLM (Harv) BA LLB Bec (Syd)

K Savell, BSc LLB (Macq) LLM (McGill) PhD (Cantab) 
Lecturers

T Anthony, BA (Hons) LLB (Hons) PhD (Syd)

A Loughnan, BA (Hons) LLB (Hons) (Syd) LLM (NYU) PhD (LSE)

K Walton, LLB (Edin) MA (UCL) PhD (Edin)

Publishing Officer

D Koester, BA (Syd)

Administration Officer

R Miller, BA (Syd) MCrim (Syd)

\section{Management Committee}

The Management Committee is comprised of the teaching and research staff and the Administrative staff of the Institute of Criminology. Additional members of the Committee are: Associate Professor E Baldry, University of New South Wales Associate Professor K Biber, University of Technology Sydney Professor D Brown, University of New South Wales Associate Professor M Carmody, University of Western Sydney Dr J Cashmore, University of Sydney Professor C Cunneen, University of New South Wales Professor G Triggs, Dean, Faculty of Law, University of Sydney

Chair

\section{Advisory Committee}

The Honourable J Spigelman, AC, Chief Justice of the Supeme Court of New South Wales Advisor to the Director

The Honourable Justice M Kirby, AC CMG, High Court of Australia Members

Mr B Barbour, New South Wales Ombudsman

The Honourable Justice RO Blanch, AM, Chief Judge, District Court, Sydney

Professor J Braithwaite, Australian National University

Mr P Byrne, SC, Barrister

Dr D Chappell, Professor, University of Sydney, Professorial Fellow, University of Wollongong

Mr P Cloran, Deputy Chief Magistrate, Local Court of New South Wales

Mr N Cowdery, AM, QC, Director of Public Prosecutions

His Honour Judge R Dive, Senior Judge, NSW Drug Court

Professor P Grabosky, Australian National University

Mr L Grant, Assistant Commissioner, NSW Department of Corrective Services

Mr A Haesler, SC, Barrister and NSW Public Defender

Professor RW Harding, Inspector of Custodial Services, Western Australia

The Honourable Justice PJ Hidden, AM, Supreme Court of New South Wales

His Honour Judge M Marien SC, Judge of the Distict Court of New South Wales

His Honour Judge SR Norrish, QC, Judge of the Distict Court of New South Wales

The Honourable Justice RNJ Purvis, AM, QC, Deputy President, Administrative Appeals Tribunal

Ms J Sanders, Youth Justice Coalition

The Honourable Justice PJ Staunton, AM, Industrial Relations Commission

Mr B Thomas, Director, Crime Prevention Division, NSW Attorney-General's Department Mr PG Ward

Dr D Weatherburn, Director, NSW Bureau of Crime Statistics and Research

Ms P Musgrave, Director, Criminal Law Review Division, NSW Attorney-General's

Department

His Honour Judge GD Woods, QC, Judge of the Distict Court of New South Wales 


\section{CURRENT ISSUES IN CRIMINAL JUSTICE}

\begin{tabular}{lcr}
\hline Volume 20 & Number 1 & July 2008 \\
\hline The Criminalisation and Punishment of Children and Young People & Special Issue: \\
CONTENTS
\end{tabular}

Phil Scraton

The Criminalisation and Punishment of Children and Young People: Introduction. . . . . . . . . . . . . . 1

\section{Articles}

Siobhán McAlister

Timo Harrikari

Chris Cunneen

Deena Haydon and Phil Scraton

Linda Moore and Una Convery

Mark Halsey

Henry A. Giroux

Tony Platt

Shadd Maruna and Anna King

Bryan A. Stevenson

Bree Carlton
Predictable Pathways? Negotiating Risk in the Context of Marginalisation and Social Exclusion ............... . 14

Exploring Risk Governance in the Nordic Context: Finnish Juvenile Crime and Child Welfare. . . . . . . . . . . . . . . . . 29

Changing the Neo-Colonial Impacts of Juvenile Justice. . . . . 43

Conflict, Regulation and Marginalisation in the North of Ireland: The Experiences of Children and Young People. . . . . . . . 59

Barred from Change: The Incarceration of Children and Young People in Northern Ireland. . . . . . . . . . . . . . 79

Pathways into Prison: Biographies, Crimes, Punishment . . . . 95

Youth in a Suspect Society: Education Beyond the Politics of Disposability ....................... 111

\section{Contemporary Comments}

The Child Savers Reconsidered. . . . . . . . . . . . . . . 123

Giving Up on the Young . . . . . . . . . . . . . . . . . . 129

Cruel and Unusual: Sentencing 13- and 14-Year-Old Children to Die in Prison . . . . . . . . . . . . . . . . . . . . . . 135

\section{Review}

In the Care of the State? Child Deaths in Penal Custody in England and Wales, Barry Goldson and Deborah Coles, Inquest, London, 2005 . . . . . . . . . . . . . . . . . . 141

Current Events 



\title{
Predictable Pathways? Negotiating Risk in the Context of Marginalisation and Social Exclusion
}

\author{
Siobhán McAlister
}

\begin{abstract}
This article is based on ethnographic research with young people living in an area of multiple deprivation in the North-east of England. The young people in this study experience many risk factors associated with social exclusion and future offending. Through in-depth examination of crime within the context of their lives, it will be argued that recent theorisations of youth crime and criminal careers do not fully capture the nature of their offending, the contextual circumstances surrounding it and the differential impact of similar risk factors on their lives. The article concludes by suggesting that not only do such theories detract from the situations of poverty and social exclusion in which young people live but that youth policies informed by them potentially add to their experiences of exclusion and marginalisation.
\end{abstract}

\section{Introduction: Young People, Risk and Regulation}

Much recent theorisation on the condition of young people in contemporary western societies - particularly the 'youth question' and 'the problem of youth crime' - has focused around discussions of risk. Despite broader theoretical debates, Smith et al (2007:219) remind us that the concept remains powerful: 'since concerns about risk lead to calls to do something about it'. It is widely accepted that young people today face changing socioeconomic conditions and circumstances and have to negotiate a different set of risks to previous generations. More traditional transitions or pathways from 'youth' to 'adulthood' are less certain and more risky than before. Yet, while all young people face increased risks they also face increased opportunities as society, social identity, lifestyles and life chances have become more individualised and less class-based (Beck 1992). From this viewpoint, class, gender, racial and or/ spatial constraints, to an extent, have diminished and people are essentially agents of their own futures.

Other analyses, however, have pointed to the persistence and entrenchment of established forms of inequality demonstrating how they continue to structure and shape

* Research Fellow, Institute of Criminology and Criminal Justice, School of Law, 28 University Square, Queen’s University Belfast, BT7 1NN, Northern Ireland email: s.mcalister@qub.ac.uk 
young people's transitions (Furlong \& Cartmel 1997; Jones 2002; MacDonald \& Marsh 2005). While the latter explanation does acknowledge there is 'an unequal vulnerability to risk’ (Furlong \& Cartmel 1997:3) the impression is that increased opportunities and choices are open to all irrespective of their background, should they wish to avail of them. Such perspectives are more likely to identify the alleged failure of young people to take the new opportunities presented by risk society, and the inability of some to plan appropriately their biographical responses to these new conditions and otherwise rehearse (again) the deficits of 'the excluded'.

Despite the critiques and concerns of this approach, people and places at risk of social exclusion, criminality, teenage parenthood and 'disconnection from the world of work', have been at the centre of New Labour social policies (see Coles 2000). Returning to Smith et al's (2007) earlier comment, notions of risk are used to justify interventions. Young people and their (potentially) risky behaviours have featured heavily in these policies as the assumption is that risks can be identified from an early age and interventions put in place. Policies and programmes are then targeted at those 'at risk' of social exclusion or of becoming future offenders. Indeed, it is instructive that many of the risk factors associated with the potential for future offending are similar to the identified characteristics of social exclusion, ${ }^{1}$ from the outset leading to the problematisation of the 'socially excluded'. Likewise 'specific forms of risk-taking behaviour are constructed through problematising discourses' (Smith et al 2007:224). Behaviour which is not criminal and may not be problematic becomes the focus for intervention, monitoring and control. Some of the most pertinent examples relate to young people, their use of free time and public space and how this has been regulated due to the 'threat' they pose.

Unsurprisingly, in this policy climate criminological theories that claim to measure, understand and identify factors most likely to 'predict' future involvement in crime have been influential. Large-scale studies on criminal careers have helped to identify a number of social and individual factors assumed to be linked to future offending. These include hyperactivity, low self-control, poor ability to delay gratification, deficits in cognitive skills, poor school performance, school truancy, lack of parental supervision, 'disrupted families', low-income and living in poor, high crime areas (see Farrington 1996, 2007; Graham \& Bowling 1995). Reflecting on his research Farrington (1994:556) claimed that persistent (or chronic) offenders 'might have been identified with reasonable accuracy at age 10 '.

Added to concerns about 'predicting' future criminal behaviour based on early behaviours, ${ }^{2}$ France (2007:99) also notes that while risk analysis does 'recognise the wider social and economic context of behaviour ... [the] main emphasis is on the failings of individuals, their families and communities'. Research into ASSET suggests that theoretically and practically the focus is on individual rather than social factors. ASSET is the standardised assessment tool utilised by Youth Offending Teams (YOT) to assess risk before and after an intervention. It identifies individual risks - 'thinking and behaviour', 'attitudes to offending', 'lifestyle' - and social risks (education, employment, living

1 The policy definition of social exclusion is that it is 'a short-hand term for what can happen when individuals or areas suffer from a combination of linked problems such as unemployment, poor skills, low incomes, poor housing, high crime environments, bad health and family background' (Social Exclusion Unit 1998).

2 While many theories of risk claim not to be about 'predicting' future criminality, this impression does nonetheless come through in some. Aside from this, MacDonald notes that 'whilst academic proponents of risk factor approaches rightly tend to demur from using risk factors to predict individual behaviour this is not always the case with some of the policy and practice outcroppings of risk theory' (2006: 378 - original emphasis). 
arrangements and neighbourhood) (in Gray 2007:405). Gray notes that despite evidence of 'severe personal and social disadvantage of young offenders', in conducting assessments YOT workers place more emphasis on individual factors as risk indicators of re-offending. She concludes:

This suggests that at the time of assessment and before any attempt at interventions, YOTs viewed the fulcrum of its complementary social inclusion and crime prevention strategies in terms of changing young offenders' way of thinking rather than their social circumstances (ibid:408-409).

Thus the most influential theories on youth crime and criminal careers and consequent policy interventions continue to focus on individual factors, deficits or maladjustments (France 2007). Further, in calculating or measuring involvement in crime over a person's life span less attention is paid to the nature and circumstances of that offending behaviour. Consequently, the social, historical and indeed spatial context of offending is often lost or under-played (see MacDonald 2006), and other external influences that impact on criminal careers - such as contact with the criminal justice system - are ignored (France 2007).

Through focusing on a group of young people who display many of the 'risk factors' associated with social exclusion and future offending this article offers a more qualitative and detailed insight into 'criminal careers'. The aim is to put the young person into the picture through viewing offending behaviour within the context of their lives - where they live, their socio-economic position and the 'choices' they make. Through this, it will be demonstrated that 'offending' in the younger years does not lead necessarily to long-term, more pronounced 'criminal careers'. Yet criminal justice policies based on the formulation of 'risk' have the potential to criminalise the everyday 'youthful behaviours' of those most excluded (see Harrikari this issue). Further, a number of 'critical moments' (Thomson et al 2002) in the lives of the young people impact at a personal level in ways that quantitativelyorientated, policy influential criminal careers research fails to capture. The article concludes by suggesting that criminal justice and other risk-based youth policies focus primarily on monitoring, regulation and control thereby contributing to the offending behaviours they are designed to reduce.

\section{Background to the Research}

The primary research was an ethnographic study carried out in a housing estate in Northeast England. It involved periods of observation and participant observation over three years alongside in-depth biographical interviews with 34 young people aged between 16 and 25.

'Blossom Hill' is typical of what have been defined as 'underclass' or 'socially excluded' neighbourhoods. Many of the cited characteristics or 'joined-up problems' of such areas prevail in Blossom Hill - low educational attainment, high levels of unemployment, low incomes, poor housing, high crime rates and high levels of single parent households. It is also recognised in official indicators as an area of multiple deprivation. At the time of data collection it was ranked in the 10 per cent most deprived wards in England and Wales and 40 per cent of the population were defined as 'income deprived'. It was ranked as the most deprived ward in $\mathrm{Kelby}^{3}$ in terms of 'Access to Services Deprivation’ (Department of Environment Transport and the Regions 2000).

3 Kelby is the pseudonym employed for the town in which Blossom Hill is located, it is the same pseudonym used by others who have also carried out research in the town (e.g. Johnston et al 2000; MacDonald \& Marsh 2005; Webster et al 2004). 
Many services once located in the area had moved out within the five years prior to fieldwork (doctors' surgery, police station, bank) and those that remained (library, recreation/youth centre; shops) were in need of regeneration. Blossom Hill was also a peripheral and physically isolated estate without affordable and reliable public transport.

Locally known as a 'problem area', its location, design and layout made Blossom Hill attractive to joyriders and the external perception is that its residents are best known for 'thievin' (stealing). A crime audit of Kelby also identified Blossom Hill as 'an anti-social hotspot area' (Kelby Police \& Kelby Council 2001). Young people living in the area agreed that there was considerable crime on the estate. Crime and/or antisocial behaviour was, for most, a 'normal' part of life, encountered on a regular basis. It was 'normalised' and when young people were not personally involved they could not escape it. For many, certain crimes were viewed as nothing out of the ordinary (Foster 1990; Garland 2000). Garland (1996:446) comments that in such neighbourhoods crime is a 'routine part of modern consciousness, an everyday risk to be assessed and managed ... a standard background feature of [their] lives'. This view, however, is not synonymous with apathetic or irresponsible attitudes towards crime nor that crime had become 'structurally normalised' in Blossom Hill to the extent that it had become the basis on which the community worked (Lea 2003). Yet the risks faced by young people, as potential victims or perpetrators of crime, were higher than in other places. Further, many young people shared other problems - truancy from school, low education attainment, poverty, parental separation.

Despite sharing similar starting points two general 'patterns of offending' were evident from young people's life accounts. First, short-term 'less serious' offending for many and, second, more pronounced and persistent offending among a smaller group. This paper focuses on the actual nature and circumstances of offending among these two groups, highlighting the risks they faced in their neighbourhood, the broader circumstances of their lives and the different means of 'managing' or 'negotiating' both. The first group's offending is best understood as a by-product of their leisure activities in their early to midteens, while the second section offers illustrative case examples of the circumstances and nature of offending by frequent, persistent and long-term offenders. The aim of both sections is to set offending behaviour in the context of the lives of the young people interviewed.

\section{Street-based Leisure: A Pathway into Crime?}

Given the lack of organised leisure activities in Blossom Hill, the estate's location and restricted finances, young people tended to spend most of their free-time in the area. The principle leisure activities of young men and women through their early to late teens took place on the streets. ${ }^{4}$ Here they would 'just knock about', 'kick the [foot]ball about', 'meet up with mates', 'mooch about', 'get pissed' ${ }^{6}$ and, occasionally 'watch TWOCkers'. Essentially, being out on the streets of Blossom Hill involved little more than passing time (see Corrigan 1976) or waiting for something to happen (see Foster 1990; Kennedy \&

4 'The streets' is a shorthand label for the various public places that young people would 'hang about' in their own neighbourhood. This included street corners, parks, around the lake, outside the shops, recreation centre or library or in public walkways/throughways.

5 Moochin' referred to the act of simply wandering, somewhat aimless, about the estate with no particular objective or purpose in mind.

6 Colloquialism for getting drunk.

7 TWOCing refers to Taking a motor vehicle Without the Owner's Consent. It contravenes the Theft Act 1968 (s12) and the Criminal Attempts Act 1981 (s9) (Yates 1999). 
Baron 1993). Leisure activities were mainly unsupervised, unregulated and unstructured. Interestingly, for some, they simultaneously induced and reduced boredom; while it was better than 'sittin' in the house' it often involved 'doin' nowt' (nothing).

For young people in their teenage years who are often granted and, indeed, crave more freedom and unsupervised leisure time, it is no surprise that they wanted to be away from home and among their peers. The streets may have appeal for a variety of reasons but for these young people there was 'nowt else to do' (Michael). Jason's response reflected others: 'There's just not much to do, there's not much erm ... there's just not much anythin'” Periods of observation and analysis of local documentation suggests that the young people's perception that there was 'nowt to do', was justified in terms of locally available youth facilities. While the recreation/ youth centre provided a possible meeting place some evenings of the week, many felt that they were too old for the centre and others were excluded for misbehaving. ${ }^{8}$ As money was restricted and public transport expensive and unreliable, they had few opportunities to take advantage of leisure facilities outside the local area.

The more 'routine activities' that took place on the streets always offered the potential for something more 'exciting' and less predictable to happen. Blossom Hill had been associated with joyriding for over 20 years, and it often happened in the centre of the estate where there were large open spaces and more chance of spectators. Watching joyriders was the most exciting aspect of Kev and Jay's time on the street:

SM: Did you hang about the streets and that when you were younger?

Kev: Yeah, just, I dunno, it was just, I dunno, you just, I used to buzz really, watchin’ the cars and that.

Jay: Just watchin', we used to just get a bottle of cider, you know, just excitin' watchin'.

The appeal of watching joyriding appeared to be that it symbolised something 'out of the ordinary', something different, and essentially something rather than nothing happening. France (2007:109) sees the spectacle as 'pleasure in a world devoid of excitement'.

Not only were the streets a place to watch crime but hanging around, consuming alcohol and meeting with others involved in the same behaviours also meant there was the potential for committing and experiencing crime. For most young people, even if fairly frequent, their offending was inherently 'petty'. It involved low-level offences against public property or what may be viewed as 'disruptive or disorderly behaviours' (Scraton 2004:143). Their presence on the street involved 'messing about' and 'having a laugh'. Many described it as 'just daft things' or 'kids stuff' which they linked to a lack of alternatives:

Joe: We just like throwed trolleys out of Danston into the lake, without the Co-op seein' anythin'.

SM: Just at night time?

Joe: No through the day sometimes (pause) we just were bored we thought lets go get some trolleys and put 'em in the lake ... That's because you had nothing to do.

Their behaviour and their explanations were not dissimilar to Wilmott's (1966:126) report of 'delinquent' (male) subcultures in late 1960s East London: 'much of what the boys [sic] are doing, is, in strictly rational terms, pointless and senseless - much of the behaviour is

8 Research suggests that young people tend to move away from using youth clubs between the ages of 14 and 16 (Geraghty et al 1997; Hall et al 1999) and further research by Brown et al (1995) in East Kelby reported that as young people entered the teenage years they began to find youth clubs restrictive. 
an expression of bubbling exuberance, of animal high spirits'. Many 'delinquent acts, ${ }^{9}$ with which they were involved - vandalism and other forms of criminal damage, drug use and alcohol consumption, trespass and general rowdy or nuisance behaviour - can be viewed as a by-product of their leisure activities. These activities could lead to circumstances in which there was the greater potential to be the victim, perpetrator or witness of crime (Agnew 2003). As Karen and Sam reflected, the potential for 'trouble' was often present, whether it was sought or not:

Sam: ... we didn’t really go lookin' for trouble like

Karen: If it come to ya, it come to ya, that was it

Sam: Well like sometimes like others, they [other groups of young people] would just come down and like want a fight.

For Blossom Hill's young people living in low income families, where youth facilities were limited and barriers to other facilities were intensified due to financial and spatial constraints, the streets were often the only place available (see also Brown 1994; EubanksOwen 1999; MacDonald \& Shildrick 2007). In Rob’s words: ‘There’s nowt for us to do, like we go up to the school to play football, and like the bobbies [police] will come and move us on and then we've got nowhere else to go apart from on the street corner. That's all it is is street corners'. Yet, when groups of young people spent time on the streets they were accused of causing a nuisance '... and seen as a problem to be solved, not as a group of people who need somewhere to meet' (Dibben 1999:6).

Like working class young people living in similarly deprived areas three decades years ago, young people from Blossom Hill spent their free-time in much the same way (see for example: Corrigan 1976; Downes 1966; Foster 1990; Jenkins 1983; Willmott 1966). While there was no pre-planned intent to cause trouble, it did happen. 'Crime' and 'delinquency' were part of youth leisure, growing up and the maturation process and were inherently short-lived. Rather than being 'immersed in a criminal culture by the time they are teenagers' (Murray 1993), they were involved, for a short period of their lives, in a working class street and leisure culture where crime was a by-product. Additionally, the risks of victimisation were increased because of this leisure activity - meeting up and fighting with other groups of young people, intra-group fights. This is rarely reported, however, in media accounts of these so-called 'streets of terror' (Scraton 2004). In fact, contrary to media depictions of 'streets of terror', the observations of young people were that little happened (as Corrigan 1976 noted 30 years ago). Indeed if the streets of Blossom Hill were consistent with those images portrayed by the media and some politicians, the young people interviewed would have been 'in the thick of it', if not as participants, certainly as observers.

While risks of crime were intensified on the street, there was no evidence that hanging around was a pathway into more persistent offending. Most young people, once they moved away from street-based leisure, tended not to be involved in criminal or antisocial behaviour associated with it, at least not to the same degree or intensity. Yet if the offences or delinquent acts committed by them during this period were enumerated, as in some criminal careers research, the assumption about future behaviour would be different. While some young people naturally moved away from street-based leisure, others made this a conscious

9 As not all the behaviours these young people were involved in constitute crime in the traditional sense of the word (e.g. underage drinking in public places breaks by-laws rather than constitutes a criminal offence), it might, on occasions, be more appropriate to refer to some of these as 'acts of delinquency' (Smith et al 2001:23). 
decision in order to manage or negotiate the associated risks. Pete, for example, gave a primary motivation for entering a Training Scheme as his desire to end involvement in crime; training was a means of filling time and keeping out of trouble. Other strategies were employed to minimise the risk of victimisation in a 'high crime environment'. Some young people regulated their movements, keeping away from parts of the estate where crime was most visible (see Mitchell et al 2004). Knowledge of the area and the local context of crime, therefore, was paramount to understanding how to protect against personal risks. Others, while spending leisure time on the street ensured they remained part of a group to be afforded 'protection'.

While not denying that some young people's actions when 'hanging about' the streets were intimidating, even threatening, Bynner (2001:16) states that such behaviours are 'fundamentally life-style indicators, which may or may not turn into problem behaviours in adulthood'. For most this was a period when their offending was at its peak. Rather than reflecting a 'way of life' it more accurately reflected a 'fact of life' at that particular time (Downes \& Rock 1998:156). Although disorderly and delinquent behaviour in Blossom Hill was possibly attributable to small transitory groups of young people, who tended to move off the streets once they hit a particular age and were then replaced by the next generation of 'street corner youth', their offending or antisocial behaviour was not necessarily a response to what earlier sub-cultural theorists refer to as 'status frustration' or 'alienation' (Downes 1966). What it does reflect is that the risk of offending behaviour and victimisation is often a by-product of lifestyle during a particular period. As Smith (1986:92) comments 'lifestyle itself is just one manifestation of more fundamental social and economic processes' - that is, it is an indicator of income and service placement inequality.

\section{Critical Moments and Criminal Careers}

The behaviours with which the smaller group of young people were involved when younger were not dissimilar to the previous group. Indeed, while their individual biographies varied greatly many of the young people had similar starting points or were presented with many of the same 'risk factors' - material poverty, 'school disaffection', parental separation, living in a poor area. Yet their 'patterns of offending' were different. It was more persistent or expansive in their younger years and/ or its intensity did not decline with age. The reasons for the peak in offending among this group were not as easily explained as a byproduct of working class leisure or having 'nowt to do', although this was often how they were introduced to crime.

Using three short case studies this section considers offending within the context of young people's lives. Increased risks and unpredictable life events potentially led further into or, alternatively, further away from a 'criminal career'. Even when individuals of similar socio-economic backgrounds and circumstances were presented with similar risks, their responses were different, further reinforcing the criticism that risk factors are poor predictors and pathways are unpredictable (Hine 2006). The reality was that 'stuff happened' (Hine 2006; Webster 2005 in MacDonald 2006) in the lives of young people and responses were often different to expectations given the findings of other risk-based criminal careers research. By providing a brief insight into the circumstances of young people's lives and their offending behaviour, something of the nature of the 'choices' open to young people are revealed. Policy-oriented criminal careers research fails to capture the dynamics of this context. 


\section{Angela}

Angela was 23 at the time of interview. Like most she had been involved in street-based leisure and some of the 'delinquent acts' associated with it, but her involvement in crime, particularly shoplifting, increased rather than decreased over time. She had left the family home at the age of 16 to live with friends in the town centre. During this time her involvement in acquisitive crime escalated and her shoplifting became more expansive and frequent. As a consequence the risks associated with it became much more serious. Of this time in her life Angela stated:

I lived with a friend and we used to go out every Friday and Saturday to [local club] and we'd rob anything to get out. I mean I have got away with a lot, I did a lot of it, I mean me father, I've been to court and me father doesn't even know I've been. (her emphasis)

It was clear that shoplifting did more than fund Angela's nights out. As well as attending college, she worked part-time in McDonalds and cleaned two pizza shops. These jobs did not, however, pay enough to sustain her change in circumstances. The financial pressures associated with independent living, and the desire to accommodate a new lifestyle of clubbing now open to her through living in the town centre, were the main reasons why her involvement in shoplifting escalated. Like other young people from Blossom Hill who made an early and largely unsupported move from the family home Angela faced numerous financial problems, and this was her response. Thomson et al (2002:350) note varying responses by young people to 'critical moments' and the importance of taking account of 'the extent to which different young people have access to the requisite resources to enable them to respond constructively to events and changing circumstances'. Despite having legitimate paid employment, Angela's earnings did not provide her with adequate resources to respond constructively to her 'critical moment' - the move to independent living.

Angela faced increased risks when she made the move to unsupported independent living. Alongside potential boredom because of a non-affordable social life, she also faced homelessness and increased poverty due to low income and constant difficulties in keeping up-to-date with rent and other living expenses. She negotiated the risks with which she was now presented through criminal means. Even through this short account more can be understood about the circumstances of Angela's life and the 'choices' available at the time when her offending was at its peak, than that revealed by quantitatively-orientated criminal careers research.

Alternatively Angela's motivations for offending could be illustrative of classic 'strain' theory in that 'socially produced aspiration ... exceeds what is obtainable through available means’ (Merton 1938 in Muncie 1999:106). Angela's response could be described as 'innovation' in that she adopted and aspired to legitimate aspirations (independent living and youth leisure) but 'solved' the problem by deviant means (shoplifting). Indeed, such 'strain' and involvement in acquisitive crime was evident in several accounts of those with more expansive or prolonged 'criminal careers'.

At the age of 18 and becoming pregnant Angela's life took a change of direction. She moved back to Blossom Hill, gave up college and her job, ended her involvement in persistent shoplifting and prepared for her child. Imminent motherhood signalled a 'critical moment' for Angela as it was an event carrying important consequences for her life and identity and she made important decisions and changes accordingly (see Thomson et al 2002:339). Yet for Angela, the 'strain' between lack of material resources and the means available to achieve them had not simply receded: 
I had the two children didn’t I so ... but it was horrible, I hated it, not havin' no money, strugglin', I still am really, especially with two children. It'd just be nice to be able to go out you know and buy them things that they want, nice things, instead of havin' to like use catalogues. (her emphasis)

Again Angela's means of a partial solution was via illegitimate means in the form of benefit fraud - claiming as a single mother when her partner was living with her. Angela's 'criminal career', therefore, did not cease with motherhood, but took a less overt and risky form. Its motivation, however, remained consistent - a lack of financial resources. If the 'choice' to commit crime is examined within the context of Angela's life, the risk of committing benefit fraud was weighed against the risk of uncertainty regarding the survival of her family. All the young mothers interviewed commented how benefits provided 'just enough to survive', and they employed various techniques of budgeting, borrowing and prioritising need in order to 'get by'. The risk of losing benefits through fraud thus putting the survival of the family in jeopardy was not entered into lightly.

\section{Michael}

Michael experienced a similar life event or 'critical moment' - the move to unsupported independent living. In contrast to Angela, his response was different and signalled a move away from crime. Taken together, his and Angela’s cases illustrate how similar experiences in the lives of young people with similar backgrounds can have different outcomes. This demonstrates that risk factors can be poor predictors of future behaviour and 'unpredictable critical moments' can have ‘unpredictable consequences’ (MacDonald 2006:379).

Michael was 16 and had been involved in persistent offending from the age of 11 . His offending took place within a group context. On moving to the area at the age of 10 eventually he associated with a group of older young men and spent almost all of his free time on the streets or in public places 'getting wrecked' (drunk and stoned). The group would 'do anythin' to get money' to buy alcohol and drugs. He said:

Theft, car theft, burglaries, vandalism, em (long pause) I done loads of kinda things, of like, even like on sites, portakabins, payphones, there's money in it isn't there? You know what I mean? Back shed burglaries, bikes ... you'd have no money and nowt to drink and nowt to smoke an' then you'd be like I think I'll go and do a burglary, you know what I mean? And that's what it was like.

Michael had moved to Blossom Hill with his mother and step-father with whom he had a poor relationship. This caused him to spend little time in the family home and more on the streets. He 'excluded himself' from full-time education at the age of 14, working in lowpaid insecure jobs. When not at work, he was on the streets 'getting wrecked'. This was his life until shortly after his sixteenth birthday when his mother moved into a refuge after being physically abused by his step-father. Michael refused to move with his mother. Working an average two days a week in a fast food restaurant he experienced a number of financial difficulties. Although Michael would have been entitled to Severe Hardship Allowance he refused to take money from the state preferring to 'benefit myself'. Despite his determination, his lack of qualifications meant that he was constantly in precarious employment and almost always subject to poor pay.

His girlfriend's family saved him from homelessness. It was this 'critical moment' or life event that led to a change in Michael's 'criminal career'. He took a conscious decision to 'settle down', to move away from his peer group and life on the streets and spend more time with his girlfriend: 'What made me really settle down was that I got a girlfriend and I had summat to do and someone to talk to in ma spare time and all that ...' While Michael and 
his girlfriend moved into rented accommodation in Blossom Hill, his circumstances changed little and their low income brought the continual risk of homelessness.

Analysis of Michael's early life and 'criminal career' suggests he experienced many risk factors associated with future offending. His involvement in criminal activity that produced money in order to buy alcohol and drugs could be interpreted as evidence of low self-control and an inability to defer gratification. He had been a regular truant and 'dropped out' of school early and there was conflict and disruption in the family and he was living on a low income. Together these could be identified as strong indicators of habitual future offending. Living on a low income and faced with homelessness Michael experienced similar risks to Angela. Yet a similar 'critical moment' in not dissimilar circumstances led in Angela's case to the escalation of crime, and in Michael's case to a marked decline in offending. A body of research points to factors that act as 'turning points' in criminal careers - gaining paid employment, finding and committing to a girlfriend/marriage, parenthood, contact with the criminal justice system, bereavement, re-engagement with family and entering the military (Farrell 2006; Graham \& Bowling 1995; MacDonald \& Marsh 2005; Sampson \& Laub 1993; Uggen 2000; Webster et al 2004). Yet few studies highlight differences in responses to similar circumstances or differences in an individual's responses over a time period (see MacDonald 2006). Further, they do not necessarily highlight the risks that can remain. Michael, having moved away from crime, was negotiating the daily risk of homelessness and poverty. Both he and his girlfriend were acutely aware that their futures were risky and uncertain, yet they employed strategies to 'get by' (Michael sought a second job; Alex borrowed from her family; together they pawned personal items).

\section{Elizabeth}

Of all the young women interviewed, Elizabeth was most heavily involved in street-based leisure when younger, yet her involvement in crime tended to increase rather than decrease when she moved away from the streets and towards education. Her return and commitment to education would not have been regarded as a risk factor. What Elizabeth's account reveals, however, is her desperation to achieve and to have an adult life more secure than that of her childhood. This could be achieved only through prolonged, serious and highly risky benefit fraud. For two years Elizabeth claimed housing benefit for a house in which she was not living. In fact she stayed with her parents. Although in full-time education she broke into the college office, stole headed paper and forged a letter saying she had left the course - this enabled her to claim unemployment benefit. She also received payment from a criminal injuries claim amounting to approximately £2000. She concealed the claim so that it did not affect her benefit payments.

Elizabeth's father worked abroad for half the year and he lived the remainder of the year unemployed in Blossom Hill. This placed considerable emotional and financial pressure on the family, and at one point the house was under threat of repossession. Her parents separated on several occasions. It was Elizabeth's experiences of instability and poverty that gave her the firm resolve to make her life different. As the following extract shows, she made a conscious decision to undertake benefit fraud as a means of financing her educational aspirations thus ensuring she could eventually leave Blossom Hill for a better future:

I was pissed off cos our Dad was out of work and he's pissed off somewhere and we had no money and I was just sick of havin' no money and I was workin' ... I had one [job] on a Saturday and like a couple of evenins' a week in like a pizza shop and one in a pub in between workin' in this pizza shop ... I was fed up of stinkin' of garlic, I was fed up with dirty men leerin' at me over the bar and I just thought, I don't wanna do this no more, I'm 
earnin' a pittance, I'm gonna go and sign on ...I was sick of bein' poor so I thought I'd use this to get out of me poverty trap ... So I fiddled the dole and the housin' benefit so I could have an easy time at college and get me qualifications cos me grades were sufferin' when I was workin' all the time.

Elizabeth put considerable effort into improving her life and potential. Despite committing serious benefit fraud she successfully reached her goal, attending university and moving to a more prosperous part of Kelby.

While Elizabeth's story could be read as an example of all that can be achieved in 'risk society', that structural issues such as poverty and family relationships can be overcome by personal agency and taking individual risks, the means open to her were limited. Returning to Merton, she held legitimate goals but achieved them through non-legitimate means. Changing patterns in education create the illusion of expanding opportunities, yet educational experiences of working class and middle class young people differ greatly (Forsyth \& Furlong 2003; Jones 2002). Again, it is important to consider the context within which Elizabeth made the 'choice' to commit crime. Essentially, she weighed the risk of benefit fraud against the risk of failing educationally, which she identified as her main route out of poverty. The structure of choices as well as available opportunities, therefore, were not 'free' or 'open' in her reality. Finally, what might have been viewed as a non-risky or risk averse factor - the move to education - unpredictably led to an increased involvement in crime, again highlighting the need to understand risk and indeed crime within the full context of young people's lives.

\section{Conclusions and Comment}

Much like Whyte’s ‘Cornerville’ (1943) and Liebow’s ‘Tally’s Corner’ (1967), Blossom Hill was known only for its problems. As Whyte states of Cornerville, its inhabitants 'appear as social work clients, as defendants in criminal cases, or as undifferentiated members of "the masses"'. There is one thing wrong with this picture: no human beings are in it' (1943:xv). In a climate where the focus is crime statistics, risk identification and crime prevention, the realities of people's lives are lost. This includes what shapes and motivates their decisions, the sheer volume of risks faced by those living in poor areas and how most, despite difficult situations, successfully negotiate their troubled circumstances.

While Blossom Hill is a high crime area and many living there have been involved in some form of crime throughout their lives, its young people - like those in similar working class areas where crime is comparatively high (Johnston et al 2000; MacDonald \& Marsh 2005; Webster et al 2004) - adopted a range of conscious strategies to 'get out of crime' and 'get by in life'. They minimised the impact and disruption of local crime on their lives. This research found that while many shared similar risk factors, few progressed to have longterm, discernable criminal careers. Additionally, the existence of particular risk factors was not useful in 'predicting' young people's future involvement in crime. Enhanced risks did not always translate into criminal actions and factors that might be viewed as riskminimising could have the opposite effect. This in-depth analysis of the risks negotiated by young people in an area of social exclusion demonstrates the need for analysis and understanding of risk and offending within the social and material context of their lives.

Interventions based on risk analysis invariably focus on people in estates such as Blossom Hill - poor people in poor places. They are viewed as among those most 'at risk' of social exclusion and offending. Whether intentionally or not, however, intervention programmes hold the potential to label and stigmatise. Parenting programmes, for example, focus on changing parenting styles and behaviours. The implicit assumption is that the 
parenting styles of the poor, lone mothers particularly, are deficient (Barlow \& Duncan 2000). With minimal emphasis on changing the broader socio-economic context of parenting (such as increased benefits, affordable childcare), the potential is that if programmes 'fail' that it is assumed to be a direct consequence of the failure of the individual. Such interventions can function as indirect forms of regulation on the lives of those thought unable to exercise self-control or discipline, those who cannot effectively negotiate and manage risks. As Galvin (2002 in Smith et al 2007:227) notes, 'Risk [is] ... a tool for blaming those who fail in the face of choice'. 'Choices', however, as the case studies above illustrate, are limited and shaped by many factors outside the individual's control - where they live, their disposable income.

Further, many assumptions and policies based on risk have the potential to further marginalise and criminalise young people living in economically deprived areas. Despite what has been shown here to be the circumstances and nature of young people's streetbased activities, young people who 'hang about' public places invariably are viewed as threats to the social order, civil society and the moral fabric of the community. These assumptions were central to Tony Blair's (2002) construction of a 'new, simpler and tougher approach to anti-social behaviour'. The philosophy is that if low level property offences and anti-social behaviour are tolerated among the young they will inevitably lead to more serious offending. The consequence is that many youth justice policies implemented by New Labour such as Anti-Social Behaviour Orders (ASBOs), Parenting Orders, Child Safety Orders and Curfew Orders, place further restraints on the leisure activities of young people (see Scraton this issue). Child curfews, used in some areas to remove children and young people from the street after 9pm, are essentially discriminatory as they 'select young people and criminalise them for doing what the rest of the population can freely do' (Smith \& Jeffs 1996 in Smith et al 2007:224). Rather than intervening early to prevent criminal behaviour ASBOs have brought young people into the criminal justice system at a young age for behaviours not legally defined as criminal (Scraton 2004). Those most affected are young people like those in Blossom Hill who spend much of their leisure time on the street due to a lack of alternatives and whose antisocial or criminal behaviour is inherently short-lived. For a government that has placed 'social inclusion' at the heart of its policies and legislation, it has failed to take account of 'the structural determinants and manifestations of social exclusion, political disillusionment and economic marginalisation' (Scraton 2004:135) thus demonising, criminalising and excluding those who are among the most excluded in society.

\section{Acknowledgements}

This paper is based on doctoral research part funded by the Economic and Social Research Council. Particular thanks go to Prof. Robert MacDonald and Dr. Colin Webster and to the editor of this special issue for their insightful comments on earlier drafts of this work. Also to the young people of Blossom Hill who gave up freely of their time to share their stories.

\section{References}

Agnew R 2003 'An integrated theory of the adolescent peak in offending' Youth and Society vol 34 no 3 pp 263-299

Barlow A \& Duncan S 2000 'Supporting families? New Labour's communitarianism and the 'rationality mistake: Part 1' Journal of Social Welfare and Family Law vol 22 no 1 pp 23-42 
Beck U 1992 Risk Society: Towards a New Modernity Sage London

Blair T 2002 ‘My Vision of Britain: Tony Blair’ The Observer 10 November

Brown S Heald M \& Sanllans C 1995 Nobody Listens? Problems and Promise for Youth provision - Interim Report on the 1995 Study of Youth Provision in East Kelby Kelby City Challenge/ Kelby Safer Cities Kelby

Brown S 1994 Whose Challenge? Youth Crime and Everyday Life in Kelby - Results of the 1993 City Challenge Youth Survey Kelby City Challenge Kelby

Bynner J 2001 'British Youth Transitions in Comparative Perspective' Journal of Youth Studies vol 4 no 1 pp 5-23

Coles B 2000 Joined Up Youth Research, Policy and Practice: An Agenda for Change? Youth Work Press Leicester

Corrigan P 1976 'Doing Nothing' in Hall S \& Jefferson T (eds) Resistance through Rituals Hutchinson London

Department of Environment Transport \& the Regions 2000 Measuring Multiple Deprivation at the Small Area Level: The Indices of Deprivation 2000 DETR London

Dibben P 1999 Young People and Social Exclusion: Speaking Out Against a Culture of Blame Paper presented at the International Conference on Young People and Social Exclusion, University of Strathclyde Glasgow, 9-12 September 1999

Downes D 1966 'British Delinquents and American Subcultural Theories' in W G Carson \& P Wiles (eds) The Sociology of Crime and Delinquency in Britain Robertson \& Co London

Downes D \& Rock P 1998 (3 ${ }^{\text {rd }}$ ed) Understanding Deviance: a guide to the sociology of crime and rule breaking Oxford University Press Oxford

Eubank-Owens P 1999 No Teens Allowed: The Exclusion of Adolescents from Public Space Paper presented at the International Conference on Young People and Social Exclusion, University of Strathclyde Glasgow, 9-12 September

Farrell S 2006 Understanding Desistance from Crime Open University Press Buckingham

Farrington D 2007 'Early Interventions: What Works in Reducing Crime’ Presentation to Prime Minister's Strategy Unit 19 October http:/www.cabinetoffice.gov.uk/upload/ assests/www.cabinetoffice.gov.uk/strategy/early_interventions_pres.pdf

Farrington D 1996 Understanding and Preventing Youth Crime Joseph Rowntree Foundation York

Farrington D 1994 'Human Development and Criminal Careers' in M Maguire M R Morgan \& R Reiner R (eds) The Oxford Handbook of Criminology Clarendon Press Oxford

Forsyth A \& Furlong A 2003 'Access to Higher Education and Disadvantaged Young People’ British Educational Research Journal vol 29 no 2 pp 205-225

Foster J 1990 Villains: Crime and Community in the Inner City Routledge London 
France A 2007 Understanding Youth in Late Modernity Open University Press Buckingham

Furlong A \& Cartmel F 1997 Young People and Social Change: Individualization and risk in late modernity Open University Press Buckingham

Garland D 2000 'The Culture of High Crime Societies: Some Preconditions of Recent 'Law and Order’ Policies’ British Journal of Criminology vol 40 pp 347-375

Garland D 1996 'The Limits of the Sovereign State: Strategies for Crime Control in Contemporary Society’ British Journal of Criminology vol 36 no 4 pp 347-375

Geraghty T Bleakey C \& Keane T 1997 A sense of belonging: Young people in rural areas of Northern Ireland speak about their needs, hopes and aspirations YouthAction Northern Ireland Belfast

Graham J \& Bowling B 1995 Young People and Crime Home Office London

Gray P 2007 'Youth Justice, Social Exclusion and the Demise of Social Justice' The Howard Journal vol 46 no 4 pp 401-416

Hall T Coffey A \& Williamson H 1999 'Self, Space and Identity: Youth Identities and Citizenship’ British Journal of Sociology of Education vol 20 no 4 pp 501-513

Hine J 2006 'Young People, Pathways and Crime: Context and Complexity' Paper presented at Pathways into and out of crime: Taking Stock and Moving Forward, De Montfort University 26 - 27 April

Jenkins R 1983 Lads, Citizens and Ordinary Kids: Working Class Youth Life-styles in Belfast Routledge \& Kegan Paul London

Johnston L MacDonald R Mason P Ridley L \& Webster C 2000 Snakes and Ladders: Young People, Transitions and Social Exclusion Policy Press Bristol

Jones G 2002 The Youth Divide JRF/York Publishing Services York

Kelby Police \& Kelby Council 2001 An Audit of Crime and Disorder in Kelby: A Consultation Report

Kennedy LW \& Baron SW 1993 'Routine Activities and a Subculture of Violence: A Study of Violence on the Street' Journal of Research in Crime and Delinquency vol 30 no 1 pp 88-112

Lea J 2003 Introducing 'Crime and Modernity', www.bunker8.pwp.blueyonder.co.uk/ misc/introcmd.html

Liebow E 1967 Tally's Corner; Washington D.C: A Study of Negro Streetcorner Men Routledge \& Kegan Paul London

MacDonald R 2006 'Social Exclusion, Youth Transitions and Criminal Careers: Five Critical Reflections on 'Risk' Australian and New Zealand Journal of Criminology vol 39 no 3 pp 371-383 
MacDonald R \& Marsh J 2005 Disconnected Youth? Growing Up in Britain's Poor Neighbourhoods Palgrave Houndsmill

MacDonald R \& Shildrick T 2007 'Street Corner Society: Leisure careers, youth (sub)culture and social exclusion’ Leisure Studies vol 26 no 3 pp 339-355

Mitchell W Bunton R \& Green E (eds) 2004 Young People, Risk and Leisure: Constructing Identities in Everyday Life Palgrave Macmillian London

Murray C 1993 ‘Underclass: The Crisis Deepens’ Sunday Times 28 February

Muncie J 1999 Youth and Crime: A Critical Introduction Sage London

Sampson RJ \& Laub JH 1995 Crime in the Making: Pathways and Turning Points through Life Harvard University Press Cambridge

Scraton P 2004 'Streets of Terror: Marginalisation, Criminalisation and Moral Renewal' Social Justice vol 3 no 1-2 pp 130-158

Smith C Stainton Rogers W \& Tucker S 2007 'Risk' in Robb M (ed) Youth in Context: Framework, Setting and Encounters Sage \& OUP London

Smith D McVie S Woodward R Shute J Flint J \& McAra L 2001 Edinburgh Study of Youth Transitions and Crime: Key Findings at age 12 \& 13, www.law.ed.ac.uk/cls.esytc/ finalreport/chapter1introduction.pdf

Smith J 1986 Crime, Space and Society Cambridge University Press Cambridge

Social Exclusion Unit 1998 Bringing Britain Together: A national strategy for neighbourhood renewal HMSO London

Thomson R Bell R Holland J Henderson S McGrellis S \& Sharpe S 2002 'Critical Moments: Choice, Chance and Opportunity in Young People's Narratives of Transition' Sociology vol 36 no 2 pp 335-354

Uggen C 2000 'Work as a Turning Point in the Life Course of Criminals: A Duration Model of Age, Employment, and Recidivism’ American Sociological Review vol 67 no 2 pp 529546

Webster C Simpson D MacDonald R Abbas M Cieslik M \& Shildrick T 2004 Poor Transitions: Young Adults and Social Exclusion Policy Press Bristol

Whyte WF 1943 (3rd ed) Street Corner Society: The Social Structure of an Italian Slum University of Chicago Press Chicago

Willmott P 1966 'Delinquent Subcultures in East London’ in W G Carson \& P Wiles (eds) The Sociology of Crime and Delinquency in Britain Robertson \& Co London

Yates J (1999) “Bad Boy Twockers": Twocking as a Gender-Based Resource for Male Working Class Youths to Accomplish Masculinity Unpublished MA/DipSW Thesis 